\title{
Spatio-temporal variations of hydrochemical and isotopic patterns of groundwater in hand-dug wells: the Cuvelai-Etosha Basin, Namibia
}

\author{
Josefina Tulimevava Hamutoko ${ }^{1}$, Heike Wanke ${ }^{1}$, Matthias Beyer ${ }^{2}$, Marcel Gaj ${ }^{2,3}$, and Paul Koeniger ${ }^{2}$ \\ ${ }^{1}$ Geology Department, University of Namibia (UNAM), 340 Mandume Ndemufayo Avenue, \\ Windhoek, Namibia \\ ${ }^{2}$ Federal Institute for Geosciences and Natural Resources (BGR), Hannover, Germany \\ ${ }^{3}$ Global Institute for Water Security, School of Environment and Sustainability, University of Saskatchewan, \\ Saskatoon, Canada \\ Correspondence: Josefina Tulimevava Hamutoko (jhamutoko@gmail.com)
}

Received: 10 November 2017 - Revised: 15 March 2018 - Accepted: 17 March 2018 - Published: 29 May 2018

\begin{abstract}
The rural population in parts of the Cuvelai-Etosha Basin (CEB) in Namibia depends on groundwater as a source for drinking and livestock watering. The aim of this study is to investigate spatial-temporal patterns for understanding water origins and recharge processes of perched aquifers in the CEB. The study uses hydrochemical data and water stable isotope signatures $\left({ }^{18} \mathrm{O}\right.$ and $\left.{ }^{2} \mathrm{H}\right)$ of samples collected during (10) ten field campaigns over a three-year period (from 2014 to 2016) originating from two regions within the basin (Ohangwena and Omusati). A clear distinction between the shallow groundwater in the Omusati and Ohangwena regions documented by TDS values, hydrochemical water types as well as the isotopic compositions of water. These differences are influenced mainly by their location in the landscape, depth to water table, the type of well infrastructure and aquifer material. Spatial and temporal variations indicate that even though these perched aquifers are both within the same basin, they are chemically different because of the rock materials in which their flow. Therefore, these differences in the water hydrochemical composition as well as the processes governing perched aquifers must be taken into account when planning groundwater management in the basin.
\end{abstract}

\section{Introduction}

More than half of the rural communities in the Namibian part of the Cuvelai-Etosha Basin (CEB) depend on groundwater as a main source of domestic water supply. The majority of people live in rural areas and are supplied by groundwater wells that tap both shallow and deep aquifers. The shallow groundwater which is trapped on both local, discontinuous impermeable layers (perched aquifers) and shallow regional aquifers is commonly tapped by traditional handdugs wells that are more affordable and cheap in comparison with deep boreholes. However, because of the shallow depth to water table and assumed small catchment of these local aquifers, the perched aquifers face both naturally and human induced challenges, e.g., population growth and agricultural activities; lack of proper water abstraction infras- tructure; lack of improved sanitation facilities and changes in the climatic regime that may promote both contamination and over-exploitation of the water resources of the shallow aquifers (Hamutoko et al., 2016). Different spatial and temporal scales are particularly important for arid environments due to the high heterogeneity associated with these environments. Ledesma-Ruiz et al. (2015) highlighted that spatial and temporal variability evaluation of major ions are commonly used in groundwater to give insight to aquifer's heterogeneity and processes controlling the groundwater chemistry. Wanke et al. (2014) described water quality from hand dug wells of different areas in Namibia, and concluded that the water in hand-dug wells is not acceptable for drinking and domestic purposes mainly because of its high turbidity, total dissolved solids (TDS), fluoride and nitrate values. Hamutoko et al. (2017) characterized the hydrochemical and 


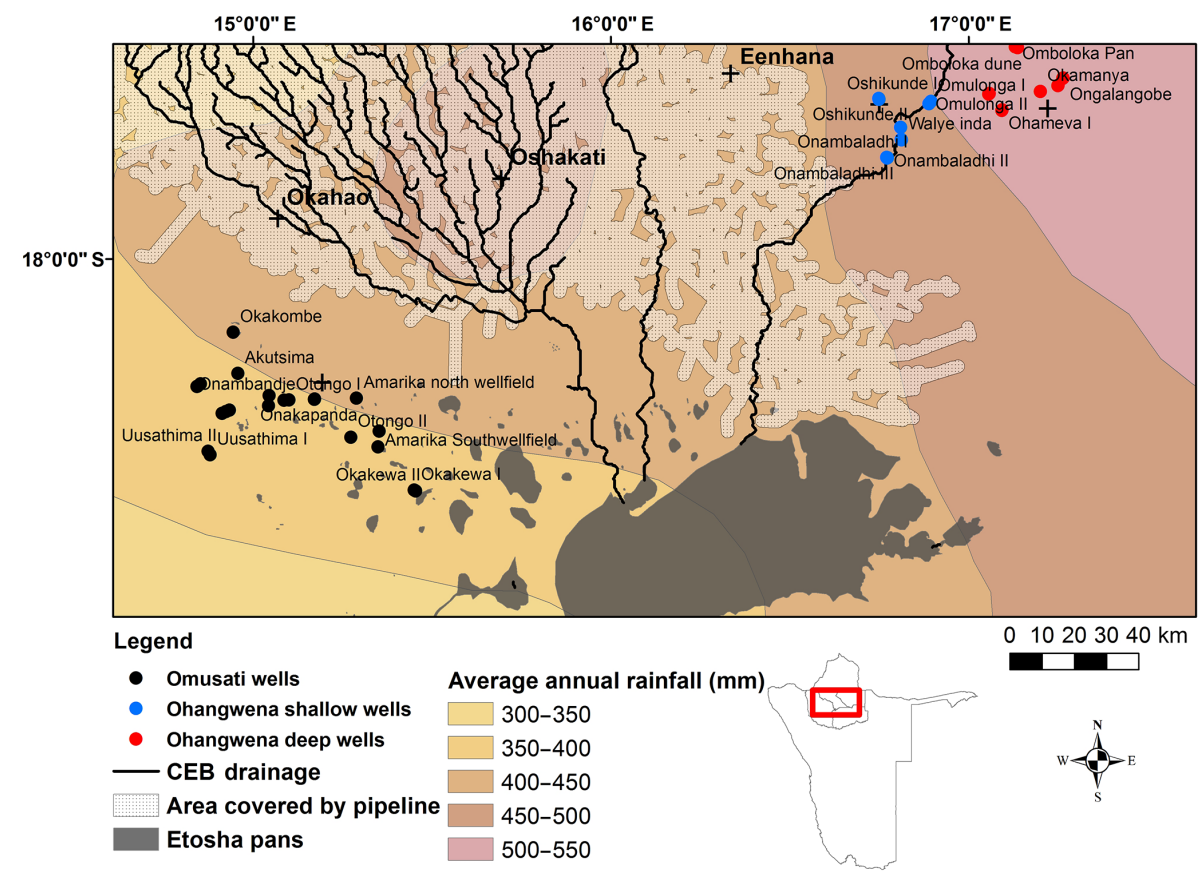

Figure 1. Location of the study area and sampling sites. The map also shows area that is connected to the national water supply pipeline.

isotopic composition of the hand-dug wells in the Ohangwena region and concluded that the groundwater is bicarbonate dominated while the isotope signatures imply recharge through both fast infiltration and diffuse recharge. Nevertheless, spatio-temporal variations of both hydrochemical composition and isotopic signatures are still not well understood and this hinders an effective management of these important shallow water resources. Hence, in this the study we sought to understand the spatial and temporal variations of major ions and water stable isotope signatures $\left({ }^{18} \mathrm{O}\right.$ and $\left.{ }^{2} \mathrm{H}\right)$, to determine the predominant processes that contribute to groundwater recharge and evolution of hydrochemistry of hand-dug wells in the CEB.

\section{Study area}

The study was carried out in the as part of the CEB (Fig. 1). CEB is the Namibian part of the Cuvelai catchment which is a huge sedimentary basin extending from the southern Angolan highlands into north central Namibia covering an area of about $165000 \mathrm{~km}^{2}$ (Lindenmaier et al., 2014). Two core study areas were defined, namely Ohangwena and Omusati regions (Table 1). The drainage system is directed towards the saline Etosha pan which is the lowest point in the basin (Fig. 1).

The Ohangwena multi-layered aquifers $(\mathrm{KOH})$ has three aquifers. In this area $\mathrm{KOH}$ consist of local perched aquifers (KOH-0) that lie between 0 and $40 \mathrm{~m}$ on top, underlain by the regional Ohangwena 1 aquifer $(\mathrm{KOH}-\mathrm{I})$ is between 60 and $160 \mathrm{~m}$ below groundwater level (m b.g.l.) and at the bot- tom is the Ohangwena 2 aquifer $(\mathrm{KOH}-\mathrm{II})$ which is between 250 to $350 \mathrm{~m}$ b.g.l. (Bittner, 2006). The Omusati multi-zoned aquifer (KOM) has a shallow depth to water table, ranging between 10 to $100 \mathrm{~m}$ with perched aquifers occurring in a fewer places as compared to the $\mathrm{KOH}$ region. The Ohangwena region is characterized by two types of hand-dug wells: shallow wells (funnel-shaped hand-dug wells) locally known as "Omifima" and the deep wells (cylindrical-shaped handdug wells) known as "Eendungu". In the Omusati region all hand-dug wells are of the funnel-shaped type. In the Ohangwena region all hand-dug wells are tapping the perched aquifers while in the Omusati region some hand-dug wells are tapping both perched aquifers and the shallow parts of the regional aquifer KOM.

\section{Sampling Methods and Laboratory Analysis}

Water samples were collected from 48 hand-dug wells, from the two core study regions. Sampling took place over a period of three years (2014-2016) within ten campaigns. Some wells were not sampled at all times because they were not in use or/and dry during the particular field campaign; thus sampling would have been unrepresentative. In the field the physical parameters $\mathrm{pH}$, electrical conductivity (EC), redox potential (Redox), oxygen content $\left(\mathrm{O}_{2}\right)$ and temperature $(T)$ were measured with Hach field portable instruments (HQ $11 \mathrm{~d} \mathrm{pH}$ meter, HQ 14d conductivity meter, HQ 40d multimeter). The water level was measured with an electrical contact gauge. Major ions and stable isotopes samples were collected following standard procedures. Chemical analy- 
Table 1. Comparison of the two core sites and main results. Source for climate data Mendelsohn et al. (2013).

\begin{tabular}{|c|c|c|c|}
\hline & Omusati wells & $\begin{array}{l}\text { Ohangwena shallow } \\
\text { wells }\end{array}$ & Ohangwena deep wells \\
\hline Precipitation $\left(\mathrm{mm} \mathrm{a}^{-1}\right)$ & $350-400$ & $450-500$ & $500-550$ \\
\hline $\begin{array}{l}\text { Potential evapotranspi- } \\
\text { ration }\left(\mathrm{mm} \mathrm{a}^{-1}\right)\end{array}$ & $2600-3000$ & $2400-2600$ & $2400-2600$ \\
\hline Local geology & $\begin{array}{l}\text { Sand, clay and cal- } \\
\text { crete/dolocrete and } \\
\text { large evaporitic } \\
\text { deposits }\end{array}$ & $\begin{array}{l}\text { Fine sands, clay and } \\
\text { calcrete }\end{array}$ & $\begin{array}{l}\text { Medium to coarse } \\
\text { grained Sand }\end{array}$ \\
\hline Water level (m b.g.1.) & $0-10$ & $0-5$ & $5-30$ \\
\hline Main water type & $\begin{array}{l}\mathrm{CaSO}_{4}, \mathrm{NaSO}_{4} / \mathrm{NaCl}, \\
\mathrm{CaMgHCO}_{3}\end{array}$ & $\begin{array}{l}\text { Mixed Cation- } \mathrm{HCO}_{3} \\
\text { NaK-mixed Anions }\end{array}$ & $\begin{array}{l}\mathrm{CaMgHCO}_{3}, \\
\mathrm{NaKHCO}_{3}\end{array}$ \\
\hline $\begin{array}{l}\text { Isotopic composition } \\
(\% \circ)\end{array}$ & $\begin{array}{l}\delta^{18} \mathrm{O}:-7.81 \text { to } 1.32 \\
\delta^{2} \mathrm{H}:-54.77 \text { to }-13.28\end{array}$ & $\begin{array}{l}\delta^{18} \mathrm{O}:-6.95 \text { to } 0.86 \\
\delta^{2} \mathrm{H}:-49.14 \text { to }-7.64\end{array}$ & $\begin{array}{l}\delta^{18} \mathrm{O}:-9.00 \text { to }-5.82 \\
\delta^{2} \mathrm{H}:-61.51 \text { to }-37.18\end{array}$ \\
\hline
\end{tabular}

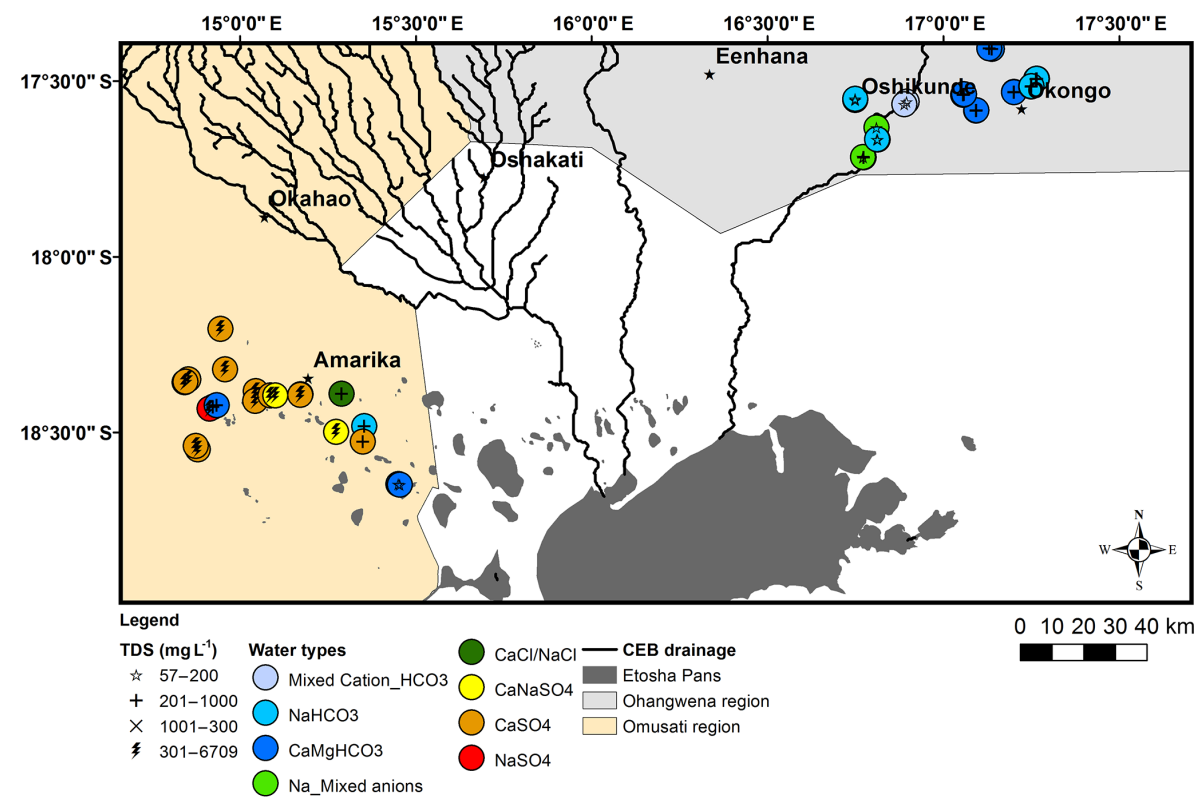

Figure 2. Spatial distribution of TDS and water types in the study area.

ses were performed at the Analytical Laboratory Services in Windhoek, Namibia and at the hydrochemistry laboratory of German Federal Institute for Geosciences and Natural Resources (BGR) in Hanover, Germany. The methods used at each laboratory is discussed in details by Hamutoko et al. (2017). Stable isotopes were measured at the University of Namibia (UNAM) and BGR laboratories using an off-axis integrated cavity output spectroscope (OA-ICOS, Los Gatos DLT-100) and a cavity ring down spectroscope (CRDS, Picarro L2120-i) respectively.

\section{Results}

\subsection{Spatial variations in water chemistry and isotopes}

Hydrochemical and isotopic data reflect spatial variability between samples from Omusati and Ohangwena regions. Average values for each elements (major ions and isotopes) were calculated for each sampled site and the average values were used to show spatial variability. Relatively high TDS values are observed in Omusati compared to the Ohangwena region (Fig. 2). In Ohangwena bicarbonate is the dominant anion whereas in Omusati the groundwater is dominated by sulphate, whereas cation varies between calcium and magne- 


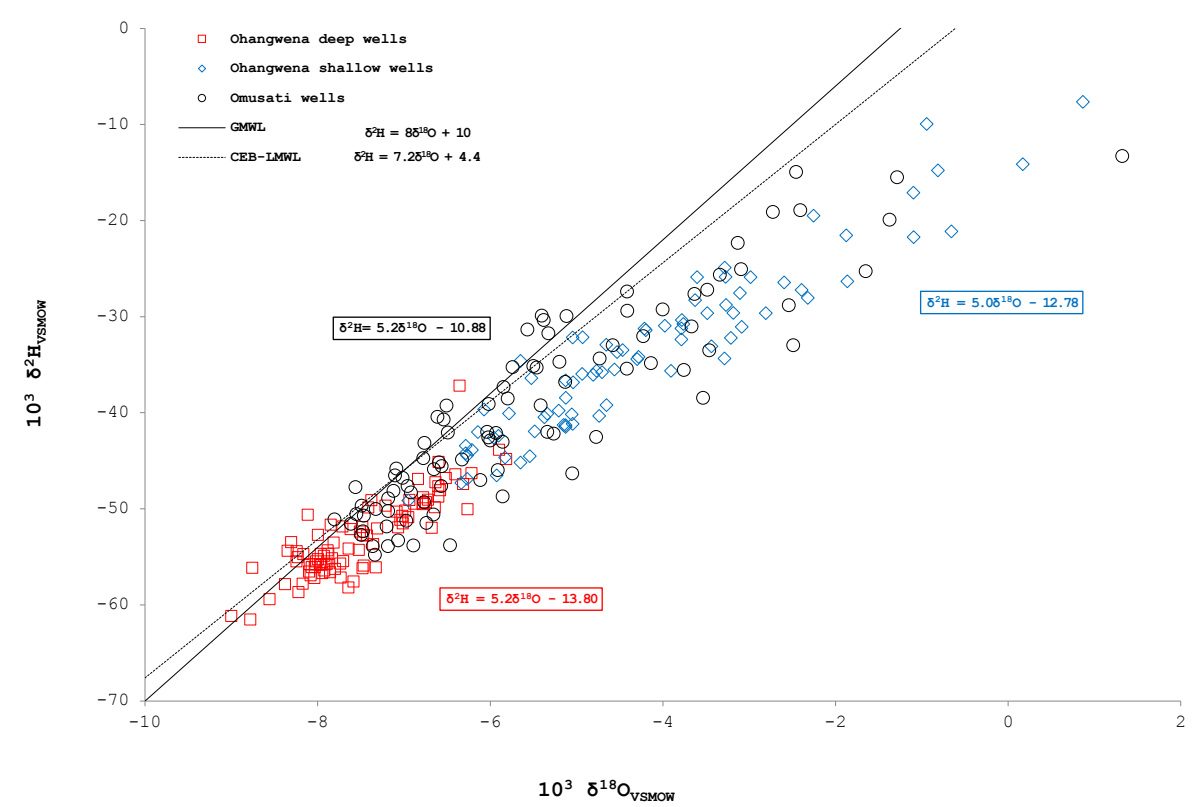

Figure 3. $\delta^{2} \mathrm{H}$ vs. $\delta^{18} \mathrm{O}$ plot of all collected samples including the global meteoric (GMWL) and local meteoric (LMWL) water lines.

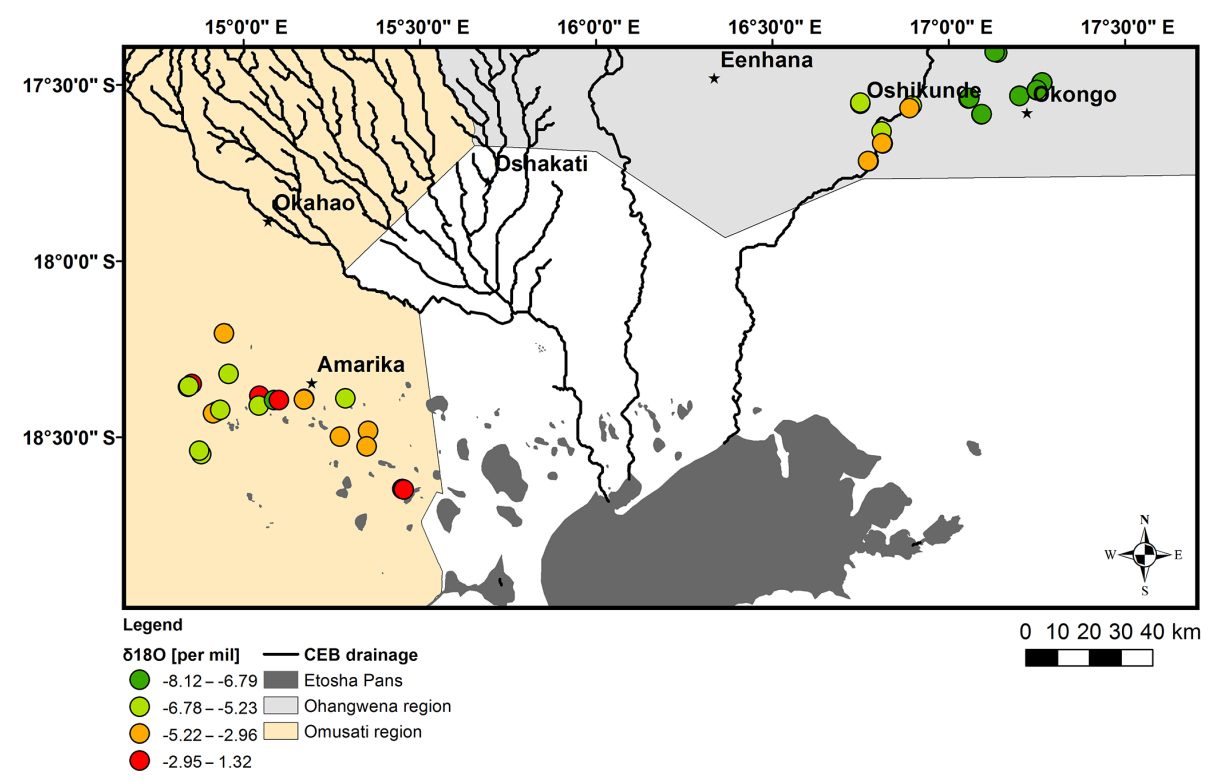

Figure 4. Spatial distribution of $\delta^{18} \mathrm{O}$ [per mil] in the Ohangwena and Omusati regions.

sium (Ca-Mg) dominated to sodium and potassium $(\mathrm{Na}-\mathrm{K})$ dominated water (Fig. 2). The stable isotope values of all collected samples are plotting close to the Global Meteoric Water Line (GMWL) (Fig. 3). The samples from the Omusati region cover a wide isotopic range from depleted to highly enriched values while in Ohangwena there are two distinct groups. One group represents samples from deep wells that are depleted in $\delta^{18} \mathrm{O}$ and $\delta^{2} \mathrm{H}$ values, and the second group comprises samples from shallow wells which are enriched in $\delta^{18} \mathrm{O}$ and $\delta^{2} \mathrm{H}$ values. Spatial distribution of $\delta^{18} \mathrm{O}$ shows that the deep wells are more depleted than the open shallow wells (Fig. 4).

In Ohangwena the deep wells plot of on regression line with equation $\delta^{2} \mathrm{H}=5.2 \delta^{18} \mathrm{O}-13.80$ while shallow wells plot of regression line with equation $\delta^{2} \mathrm{H}=5.0 \delta^{18} \mathrm{O}-$ 12.78. The samples from Omusati plot on regression line with equation $\delta^{2} \mathrm{H}=5.2 \delta^{18} \mathrm{O}-10.88$. These lines intersect the LMWL at $(-8.7,-58.2),(-7.8,-51.8)$ and $(-8.6,-57.5)$ for Ohangwena deep wells, Ohangwena shallow wells and Omusati wells respectively. 

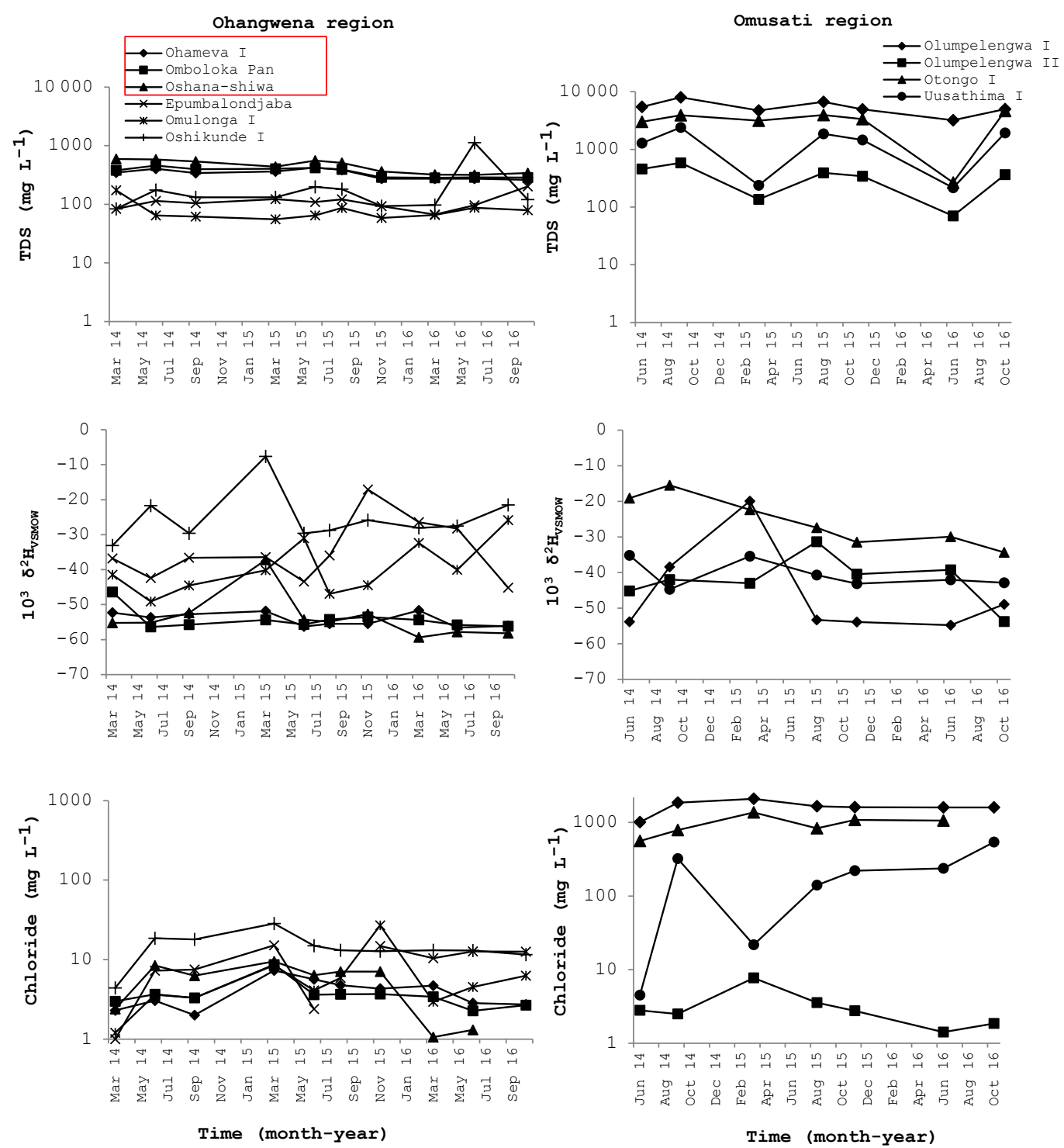

Figure 5. Temporal variation of TDS, $\delta^{2} \mathrm{H}$ and chloride concentrations of shallow groundwater in Ohangwena and Omusati regions. The villages in the red box represent deep wells from the pan/depression.

\subsection{Temporal variations in $\mathrm{Cl}$, TDS and $\delta^{2} \mathrm{H}$}

Temporal patterns were observed for $\mathrm{Cl}$, TDS and $\delta^{2} \mathrm{H}$ for ten hand-dug wells. In Ohangwena region, the change in isotope values and chloride concentration follows a similar trend, during rainy season (e.g. March to June in 2015 and 2016) chloride decline and isotope values become depleted while during dry season, isotopes become enriched and chloride concentration increases (Fig. 5). In the Omusati region TDS increases during dry seasons and reduces during rainy season. A change in $\mathrm{Cl}$ content is observed between the different years of sampling, however no trend could be identified.

\section{Discussions}

This study reveals a clear distinction between the shallow groundwater in the two regions Omusati and Ohangwena. This is documented by the TDS values, hydrochemical water types as well as the isotopic compositions of water. TDS is generally higher in Omusati than in Ohangwena. The spatial heterogeneity is controlled mainly by their location in the landscape, depth to water table, the type of well infrastructure, lithological and climatic factors. The main water types $\left(\mathrm{CaSO}_{4}, \mathrm{NaSO}_{4}\right.$, and $\left.\mathrm{CaNaSO}_{4}\right)$ in Omusati region typically originate from dissolution of evaporitic rocks (i.e. gypsum) and evaporation and they are associated with discharge areas. Thus pans in Omusati are characterized as discharge zones 
rather than recharge zone. Furthermore, Omusati region is close Etosha pan as seen in Fig. 1 which is the discharge area for the whole basin. On the other hand, pans in Ohangwena are characterized by $\mathrm{CaMgHCO}_{3}$ and $\mathrm{NaHCO}_{3}$ water types. $\mathrm{CaMgHCO}_{3}$ are common in recharge zones and normally infer fast infiltration through preferential paths or can result from dissolution of calcite and dolomite when they react with $\mathrm{CO}_{2}$ rich water (Freeze and Cherry, 1979). $\mathrm{NaHCO}_{3}$ are commonly formed as result of silicate weathering and cation exchange while mixed water type in the ephemeral river could indicate mixed water sources.

Since all the collected samples are plotting close to the LMWL and within the range of modern local precipitation, this implies that these aquifers in both regions were recharged under climatic conditions similar to modern climate. The water in the deep wells in Ohangwena and in Omusati wells have a slightly depleted source water $(-8.7$, $-58.2)$ and $(-8.6,-57.5)$ respectively. This could indicate that recharge to the aquifers which these wells are tapping from is limited to larger amount events while for the shallow wells also small amount events are contributing as the mean parent water source is slightly enriched $(-7.8,-51.8)$. In addition, the deep wells are plotting closer to the LMLW this indicates that the component from recharge without significant evaporation is larger than for the shallow wells. Samples from the shallow (open funnel-shaped) hand-dug wells are enriched in $\delta^{18} \mathrm{O}$ and $\delta^{2} \mathrm{H}$ irrespective of their latitude or longitude and they are strongly affected by evaporation due to exposure to the atmosphere. Bittner (2006) highlighted that high evaporation rates in the CEB causes the drying up of pans and ephemeral rivers resulting in the precipitation of salt and increased salinity of the shallow aquifers, in particular in waterlogged areas and areas comprising a low permeable lithology. It was also established that hand-dug wells in Omusati are tapping from both the perched aquifer and the regional aquifer and it is sometimes difficult to determine from which aquifer each well is tapping as the regional aquifer has a relatively shallow water table.

Temporal variations within each region are different for both regions. In Ohangwena temporal patterns were mainly observed in chloride and isotopes. The decrease in chloride content and isotopes during rainy season indicate recharge events and visibly they occur at different times depending on the rainfall. It is interesting to notice that the recharge events occur in the same period even though the aquifers have different depths to water table. If one assumes they are recharged by same rainfall events and same mechanisms, it would be expected that recharge will be delayed for the deep wells because of the percolation distance of the water to reach the aquifer in comparison to the shallow wells. Therefore, the results that the shallow wells and deep wells in Ohangwena are recharged through different mechanisms, whereby the deep wells are recharged through fast preferential paths and shallow wells by diffuse recharge. In Omusati the change is in Chloride and isotopes is observed but not following a par- ticular pattern, however TDS increases during dry season. This indicates dissolution of evaporites and evaporation as the dominant process that influences the change. It should be noted that the in both regions, the sampled wells are used for water abstraction, but there are no estimation of how much is extracted and thus this could have an impact on accounting for temporal variations.

\section{Conclusions}

In the present study, it could be shown that it is indeed possible to clarify the hydrogeological complexities of heterogeneous perched aquifers using isotopic and hydrochemical tracers at different spatial and temporal scales. A distinct spatial difference between samples from Omusati and Ohangwena regions. The spatial heterogeneity as shown by the TDS, hydrochemical water types and chloride can be attributed to lithological and climatic factors. Deep wells are recharged by fast infiltration through preferential flow paths during large rainfall events while shallow wells can be recharged even by lighter events. The hydrochemical water types implies that pans in Ohangwena are recharge zones while in Omusati they are discharge zones. There are no piezometers and boreholes in these perched aquifers so far and thus the water level fluctuation data is missing. Therefore it's recommended, to establish monitoring stations for both water levels and water quality. This will also enable calculation of the current the abstraction rates from the perched aquifer.

Data availability. Individual data are available from the author(s) on request.

Author contributions. All authors were involved in the field work, interpretation of data and reviewing of the manuscript. PK was leading the hydrochemical analysis while HW analysed the stable isotopes. JTH prepared the manuscript with contributions from all co-authors.

Competing interests. The authors declare that they have no conflict of interest.

Special issue statement. This article is part of the special issue "Understanding spatio-temporal variability of water resources and the implications for IWRM in semi-arid eastern and southern Africa". It is a result of the IAHS Scientific Assembly 2017, Port Elizabeth, South Africa, 10-14 July 2017.

Acknowledgements. This work forms part of PhD study undertaken at the University of Namibia. This work was partly funded by the German Federal Ministry for Education and Research (BMBF) 
within the SASSCAL project (Southern African Science Service Centre for Climate Change and Adaptive Land Management) under contract number 01LG1201. The work also benefited from the National Commission of Research Science and technology (NCRST) grant under project code ncrst/phd/012. We thank the local communities' for access to sample their wells. We thank UNAM staff and local authorities who assisted in fieldwork. We kindly thank the staff at the BGR hydrochemical laboratory for analysing samples. Benjamin Mapani, your proof reading is highly appreciated.

Edited by: Hodson Makurira

Reviewed by: Richard Owen and one anonymous referee

\section{References}

Bittner, A.: Desk study report: Cuvelai-Etosha groundwater investigation. Windhoek, retrieved from: http://www.the-eis.com/data/ literature/CuvelaiDeskStudyReport_Version1.1.pdf (last access: March 2018), 2006.

Freeze, R. A. and Cherry, J. A.: Groundwater, Prentice-Hall, Englewood Cliffs, USA, 1979.

Hamutoko, J. T., Wanke, H., and Voigt, H. J.: Estimation of groundwater vulnerability to pollution based on DRASTIC in the Niipele sub-basin of the Cuvelai Etosha Basin, Namibia, Phys. Chem. Earth, 93, 46-54, https://doi.org/10.1016/j.pce.2015.12.007, 2016.
Hamutoko, J. T., Wanke, H., Koeniger, P., Beyer, M., and Gaj, M.: Hydrogeochemical and isotope study of perched aquifers in the Cuvelai-Etosha Basin, Namibia, Isotopes Environ. Health Stud., 53, 382-399, https://doi.org/10.1080/10256016.2016.1273913, 2017.

Ledesma-Ruiz, R., Pasten-Zapata, E., Parra, R., Harter, T., and Mahlknecht, J.: Investigation of the geochemical evolution of groundwater under agricultural land: A case study in north-eastern Mexico, J. Hydrol., 521, 410-423, https://doi.org/10.1016/j.jhydrol.2014.12.026, 2015.

Lindenmaier, F., Miller, R., Fenner, J., Christelis, G., Dill, H. G., Himmelsbach, T., and van Wyk, B.: Structure and genesis of the Cubango Megafan in northern Namibia: implications for its hydrogeology, Hydro. J., 22, 1307-1328, https://doi.org/10.1007/s10040-014-1141-1, 2014.

Mendelsohn, J. M., Jarvis, A., and Robertson, T.: A profile and Atlas of the Cuvelai-Etosha basin: RAISON \& Gondwana collection, Windhoek, Namibia, 2013.

Wanke, H., Nakwafila, A., Hamutoko, J. T., Lohe, C., Neumbo, F., Petrus, I., and Quinger, M.: Hand dug wells in Namibia: An underestimated water source or a threat to human health?, Phys. Chem. Earth, Parts A/B/C, 76-78, 104-113, https://doi.org/10.1016/j.pce.2015.01.004, 2014. 